\title{
Group Cohesion for Enhanced Operation of Agricultural Community-Based Projects in Gauteng Province, South Africa
}

\author{
B. Taruvinga ${ }^{1}$, P. Ndou ${ }^{1}$, C. P. du Plooy ${ }^{1}$, K. Mphafi ${ }^{1}$, I. N. Hlerema ${ }^{1} \&$ R. Seturumane ${ }^{2}$ \\ ${ }^{1}$ Agricultural Research Council—Roodeplaat, Vegetable and Ornamental Plant Institute (ARC-VOPI), Pretoria, \\ South Africa \\ ${ }^{2}$ Gauteng Department of Agriculture and Rural Development (GDARD), South Africa \\ Correspondence: P. Ndou, Agricultural Research Council-Roodeplaat, Vegetable and Ornamental Plant \\ Institute (ARC-VOPI), Private Bag X293, Pretoria 0001, South Africa. E-mail: NdouP@arc.agric.za
}

Received: February 2, $2021 \quad$ Accepted: March 21, $2021 \quad$ Online Published: April 15, 2021

doi:10.5539/jas.v13n5p161 URL: https://doi.org/10.5539/jas.v13n5p161

\begin{abstract}
Collective operation of smallholder farmers and cooperatives has been attributed to many mishaps and malfunctions. Such knowledge creates misperceptions regarding agricultural cooperatives and their usefulness in development. This study investigated member commitment, group cohesion and membership retention in agricultural production cooperatives. The main aim was to identify possible practical measures for enhanced performance and increased sustainability in farmer organizations. Data was collected from 92 participants that were currently operating as cooperative members. A combination of descriptive statistics, Perceived Cohesion (PC) and Binary Logistic Regression methods were employed for analysis. Results of the study indicate that group cohesion is influenced by trust among members, internal communication, financial performance of the cooperative, involvement of members in decision making, and role of the organization in the community. Strategies for increased group cohesion that were recommended in the study include information sharing and transparency at all levels of operation, and collective decision making and planning in organizations.
\end{abstract}

Keywords: cooperative organizations, smallholder farmers, commercialization, cohesion

\section{Introduction}

Commercialization of smallholder and emerging farmers is receiving increasing support from the South African government, especially through policy reforms and public investment. Commercialization is advocated because it plays a vital role in minimizing poverty and food insecurity, and in enhancing food production and income generation, which boost the overall development of the agricultural sector (DAFF, 2010; Khapayi \& Celliers, 2016). In a rural economy, increased agricultural commercialization contributes substantially to labour absorption. Thus, several jobs are created from direct employment on the farms, as well as from other linked services created through multiplier effect in the input and out markets (Wiggins et al., 2011).

As much as commercialization is advocated, it has proven impractical for individual smallholder farmers in certain instances, due to an array of challenges that are faced by the farmers in both production and marketing (Khapayi \& Celliers, 2016). For instance, the majority of smallholder farmers lack capital, infrastructure, mechanization, adequate labour and knowledge, collateral, bargaining power and access to lucrative markets. In some situations, they fail to access production land as individuals. In cases where commercialization of individual farmers is impractical, farmers are often encouraged to operate collectively in cooperative organizations, which are also known as Community-Based Projects (CBPs). Collective farming is generally supposed to benefit members (farmers engaging in collective farming) through shared responsibilities, increased access to resources, enhanced economies of scale, risk reduction, establishment of countervailing power, auxiliary services, and improved positioning in mainstream agriculture (Ito et al., 2012; Yang et al., 2013). On overall, effective collective farming provides a governance structure with implicit cost-savings and risk-sharing devices (Francesconi \& Heerink, 2011).

It is indisputable that agricultural production cooperatives (hereafter CBPs) have far-reaching benefits, however, they are also known for their high failure risk (Garnevska et al., 2011). There is enough evidence in literature showcasing the inability of several CBPs to meet the intended objective of commercialization. CBPs often face 
challenges of high governance costs (resulting from collective ownership and decision-making), power struggles, opportunistic behaviour and pursuance of personal agenda by few influential members (Paulus, 2012; Bernard et al., 2013; Nkonki-Mandleni \& Anim, 2014). Nonetheless, some CBPs successfully operate and manage to bring tangible benefits to their members. This suggests that there exist certain elements in each CBP which either permit or restrict the functioning and performance of an organization. According to Paulus (2012), when members are committed, they willingly work together to complete tasks and achieve group goals. In addition, when members value their group membership, they actively seek to remain part of the group by adhering to the objectives of the group. Based on this background, the current research investigated the factors that influence member commitment to their CBP and their willingness to remain part of the organization. The research is intended to identify possible practical measures for enhancing performance and sustainable operation of farmer organizations.

\section{Conceptual Framework}

\subsection{Cooperative Relations in Agricultural Production}

A cooperative is defined by the International Cooperative Alliance as "an autonomous association of persons united voluntarily to meet their common economic, social, and cultural needs and aspirations through a jointly-owned and democratically-controlled enterprise" (ICA, 1995). Cooperatives have a long history in many parts of the world, including Africa. However, they have recently received increased attention in Africa as a tool for alleviating poverty and socio-economic development (Wanyama et al., 2009; Develtere et al., 2008). There are different types of cooperatives in different economic sectors; depending on the activities that they are engaged. Agricultural cooperatives can be categorised into production and marketing cooperatives; can either be legally registered or not; and can take any size and scope (FAO, 2012). For the purposes of this publication, the word cooperative refers to agricultural producer organizations. These organizations encompass joint production and income-generating activities, risk-sharing and profit-sharing.

In principle, agricultural producer organizations are established to help farmers reap greater benefits through increased yields and incomes; by pooling their resources together. As they operate jointly as an organization, their bargaining power is enhanced, as well as their access to market information, agricultural resources and external support services (Getnet \& Anullo, 2012; FAO, 2012). These are all necessary conditions that allow for commercialization of smallholder farmers (Francesconi \& Heerink, 2011). Whilst cooperatives are often formed with good intentions, several challenges can emerge which cause ineffectiveness, and eventually lead to the dissolution of the cooperative. These challenges include structural and managerial problems, dependence syndrome, opportunistic behaviour, limited participation and commitment of members, limited external support, limited capacity to perform effectively, unfulfilled expectations and conflicting agendas (Bernard et al., 2013; Getnet \& Anullo, 2012).

Several authors indicated that the effectiveness, sustainability and success of any cooperative are highly dependent on the commitment of its members and their ability to patronize the cooperative. If members are not committed to their cooperative, they often lack the motivation to perform optimally towards the activities of that cooperative (Jussila et al., 2012; Paulus, 2012; Bijman \& Verhees, 2011). Paulus (2012) decomposes member commitment into loyalty, identity and participation.

\subsection{Group Cohesion}

Group cohesion refers to a sense of attraction or a bond that pulls people towards membership in a certain group and a feeling of morale associated with their membership in that group. It further measures the strength of members' desire to remain in a group (group pride), their sense of belonging and their commitment to it. Members who lack a sense of belonging to the group would not desire to continue associating with their cohorts (Forsyth, 2006; Paulus, 2012). One of the presumptions on the subject of group cohesion is that it influences group task performance. Thus, teams that have a strong bond and committed members, who take pride in their group, are often motivated to achieve organizational goals and objectives (Paulus, 2012; Bijman \& Verhees, 2011). According to Hansen et al. (2002), group cohesion occurs when members have a positive feeling towards each other and the group at large. That way, they can easily relate to each other and work towards set targets. The ability of a group to be more or less cohesive is dependent on several factors, such as past group experiences, stage of the group, size of the group, time spent together, the level of trust among members and similarities of members (Gikunda \& Lawver, 2019; Evans \& Dion, 2012; Paulus, 2012). In principle, group cohesiveness can be easily developed when group members have similar values, aspirations and beliefs, and when they feel that they can trust each other. In addition, group sizes need to be monitored, in order to maintain a high level of cohesion (Gikunda \& Lawver, 2019). 


\section{Methods}

The study employed a survey methodology to collect primary data, where a semi-structured questionnaire was utilized for data collection, through face-to-face interviews. To collect relevant data, nine community-based projects (CBPs) were selected randomly from the list of projects obtained from the Gauteng Department of Agriculture and Rural Development (GDARD), and all members belonging to the 9 CBPs were interviewed, giving a total of 92 respondents. While carrying out interviews, research ethics were followed, where respondents were assured of confidentiality of the information they provided. Table 1 provides the details of 9 CBPs in the study. As part of confidentiality agreement, community-based projects were referred to as CBP 1 , CBP 2 up to CBP 9.

Table 1. Details of community-based projects in the study

\begin{tabular}{|c|c|c|c|c|}
\hline CBP Name* & Municipality* & Year established & Land size (ha) & Number of respondents \\
\hline 1 & Sedibeng DM & 2007 & 0.75 & 4 \\
\hline 2 & City of Ekurhuleni MM & 2008 & 2.8 & 13 \\
\hline 3 & City of Tshwane MM & 2000 & 7.0 & 7 \\
\hline 4 & West Rand DM & 2014 & 2.5 & 5 \\
\hline 5 & City of Johannesburg MM & 2012 & 0.4 & 5 \\
\hline 6 & City of Tshwane MM & 2009 & 2.5 & 11 \\
\hline 7 & City of Ekurhuleni MM & 2005 & 3.2 & 16 \\
\hline 8 & City of Tshwane MM & 2014 & 4.0 & 22 \\
\hline 9 & West Rand DM & 2011 & 2.0 & 9 \\
\hline Total & & & & 92 \\
\hline
\end{tabular}

Note. * There are abbreviations under these columns (CPB: Community-Based Project; DM: District Municipality; MM: Metropolitan Municipality).

Source: Field survey, 2019.

Data obtained from the survey was analysed using both qualitative and quantitative analysis tools. Qualitative data was analysed through interpretation and conceptual generalization and a mix of quantitative methods were employed to analyse quantitative data. These include descriptive statistics, Perceived Cohesion (PC) and Binary Logistic Regression analysis. Perceived Cohesion and Binary Logistic Regression analysis addressed in detail the focal point of the study. They were both used for analysing member commitment, willingness to belong to an organization and group cohesion in CBPs in the study. To analyse the data, Statistical Package for Social Science (SPSS version 24) software was used.

\subsection{Perceived Cohesion}

The analysis of Perceived Cohesion originated with Bollen and Hoyle (1990). It measures an individual's sense of belonging to a particular group and his or her feelings of morale associated with membership in the group. It is understood that a sum of group members' individual perceptions characterise the cohesion of the entire group because the individual's perceptions inform their behaviour as well as that of the entire group. Bollen and Hoyle (1990) identified the importance of perceived cohesion at individual and group levels. At individual level, perceived cohesion reflects the role of the group in the lives of group members; and at group level, it reflects the role of individuals in the life of the group.

In order to measure perceived cohesion, Bollen and Hoyle (1990) developed a set of analysis measures known as Perceived Cohesion Scale (PCS). This is a six-item measure reflecting the two underlying dimensions of cohesion; a sense of belonging and feelings of morale. The perceived cohesion measure is attached on Appendix A. The contents of the PCS were captured in the questionnaire that was developed for this study. Responses from the PSC were rated using a five point Likert scale ranging from 1 (strongly disagree) to 5 (strongly agree). The individual responses were then used to construct mean scores of each group and draw conclusions on group cohesiveness.

\subsection{Binary Logistic Regression Model}

A Binary Logistic Regression Model (BLRM) was employed to investigate the factors that influence group cohesion in CBPs. The model was used to predict the likelihood of developing strong inseparable bonds in 
community-based projects. A binary logistic regression model is used to predict the probability of occurrence of a certain event (dependent variable), based on continuous and/or categorical independent variables, where the dependent variable is dichotomous. The use of logistic regression model is valuable when dependent variables are qualitative in nature (Hilbe, 2015). In BLRM, a single outcome variable $Y_{i}$ follows a Bernoulli probability function that takes the value of 1 with probability $P_{i}$ and 0 with probability $1-P_{i}$. The value of $P_{i}$ varies over the observations as an inverse logistic function of a vector $X_{i}$. In the equation, $P_{i} /\left(1-P_{i}\right)$ refers to the odds of an event occurring (Hilbe, 2015).

A typical logistic regression model is of the form:

$$
\operatorname{Logit}\left(\mathrm{P}_{\mathrm{i}}\right)=\ln \left(\frac{\mathrm{P}_{\mathrm{i}}}{1-\mathrm{P}_{\mathrm{i}}}\right)=\beta_{0}+\beta_{1} \mathrm{X}_{1}+\ldots+\beta_{\mathrm{n}} \mathrm{X}_{\mathrm{n}}+\mathrm{U}
$$

Where, $P_{i}=$ probability of presence of the characteristic of interest; $1-P_{i}=$ probability of absence of the characteristic of interest; $\beta=\left(\beta_{1}, \beta_{2}, \ldots \beta_{n}\right)=$ coefficients; $X=\left(X_{1}, X_{2}, \ldots X_{n}\right)=$ explanatory (independent) variables and $U=$ error term.

In the current study the dependent variable is represented by group cohesiveness, where the existence of strong group cohesion takes the value of 1 , and the absence of strong group cohesion takes the value of 0 . The dependent variable in the study captures the elements of group cohesiveness, i.e., a feeling of morale, a sense of belonging and commitment to the group. The independent variables in the logistic regression were chosen based on wide literature reviewed on the subject of group cohesion. Seventeen variables were chosen and incorporated in the logistic regression model as summarised in Table 2, including their description. The variables were categorized into demographic, economic, organizational, psychological and social factors. Statistical Package for Social Sciences (SPSS version 24) was used to run the Binary logistic regression analysis.

Table 2. Description of independent variables used in the model

\begin{tabular}{|c|c|c|}
\hline Category & Variable & Description \\
\hline \multirow{3}{*}{ Demographic } & Gender & Gender of the member $($ dummy; female $=0 ;$ male $=1)$ \\
\hline & Education & Level of education of the member \\
\hline & Age & Age of the member (years) \\
\hline \multirow{3}{*}{ Economic } & Financial performance & Direct monetary benefits from the CBP \\
\hline & Value addition practice & Involvement of the $\mathrm{CBP}$ in value adding practices \\
\hline & Accessibility of CBP produce to members & The ability to access produce from CBP at an advantage \\
\hline \multirow{5}{*}{ Organizational } & Communication within the CBP & Competence in information dissemination within the CBP \\
\hline & Leaders' capability & Competence and reliability of CBP leadership \\
\hline & Involvement in decision making & Members' involvement in decision making in the CBP \\
\hline & Training & Access to training through the $\mathrm{CBP}$ \\
\hline & External influence & Level of external influence in CBP activities \\
\hline \multirow{4}{*}{ Psychological } & Trust & General level of trust among group members \\
\hline & Group size & Total number of members \\
\hline & Group stage & Number of years in operation \\
\hline & Group composition & The level of homogeneity among members regarding their interests and goals \\
\hline \multirow{2}{*}{ Social } & Member social networking & Friendships among members of the same CBP \\
\hline & Role in the community & Contribution of the CBP towards the betterment of the community \\
\hline
\end{tabular}

\section{Results and Discussion}

Based on the data gathered from the survey, the nine CBPs in the study are highly diverse in terms of the number of group members, the structure of the CBP, years in operation, size of land, the choice of crops under production, involvement in marketing and the choice of markets, amongst others. Some of these differences in the CBPs have influenced the operations and the functionality of the CBPs as discussed in detail under descriptive and binary logistic regression results. Although the nine CBPs differ widely, they share a common characteristic that they are all located in urban or peri-urban areas. These areas are characterised by land scarcity, especially for agricultural purposes. In fact, the sites of five out of nine CBPs were former dumping sites that were converted to agricultural production sites. It is noteworthy that all CBPs in the study were allowed access to agricultural land because they were operating in a group. 
In six out of nine CBPs, the projects became operational due to the existence of a visionary leader in the group. In these cases the visionary leader was actively involved in recruiting other group members. When all CBPs commenced, all members received a stipend from the government departments, for at least the first two years of operation, to allow them to stabilize. Thereafter, the projects were expected to generate enough money to fend for the members. As expected, the withdrawal of the stipend resulted in the withdrawal of some members from the CBPs. However, the rate at which group members withdraw from the group differs from one CBP to the other.

\subsection{Descriptive Results}

Descriptive results of the study include the results on demographic characteristics of members in community-based projects. According to Francesconi and Heerink (2011), there is normally a relationship between demographic characteristics of the members and their commitment to the cooperative. For instance, Trechter et al. (2002) posited that the members' commitment level declines as the level of formal education of a member increases. Hakelius (1999) established that young members often commit to their cooperatives for economic benefits, while older members view cooperatives as a means to show solidarity with peers. Demographic characteristics of members also influence their participation in decision making in the cooperatives (Francesconi \& Heerink, 2011)

Table 3 summarizes the respondents' gender, age, educational level, social status in the community and access to training on cooperative relations. There were slightly more male respondents $(54.3 \%)$ as compared to female respondents (45.7\%). These results give an impression that the participation of males and females in agricultural cooperatives was almost balanced. However, by zooming in each of the CBP, the results show that there are some CBPs that are male-dominated and some female-dominated. Actually, one of the CBPs had only young male members.

Table 3. Demographic characteristics of respondents

\begin{tabular}{|c|c|c|}
\hline Respondent characteristic & Frequency & Percent \\
\hline \multicolumn{3}{|l|}{ 1. Gender } \\
\hline Male & 50 & $54.3 \%$ \\
\hline Female & 42 & $45.7 \%$ \\
\hline \multicolumn{3}{|l|}{ 2. Age (years) } \\
\hline$\leq 35$ & 38 & $41.3 \%$ \\
\hline $36-59$ & 46 & $50.0 \%$ \\
\hline$\geq 60$ & 8 & $8.7 \%$ \\
\hline \multicolumn{3}{|l|}{ 3. Educational status } \\
\hline No formal education & - & - \\
\hline Primary & 19 & $20.7 \%$ \\
\hline Secondary & 73 & $79.3 \%$ \\
\hline Tertiary & - & - \\
\hline \multicolumn{3}{|l|}{ 4. Social status in the community } \\
\hline Community development recognition & 4 & $4.4 \%$ \\
\hline Religious affiliation & 7 & $7.6 \%$ \\
\hline Political affiliation & 5 & $5.4 \%$ \\
\hline None & 76 & $82.6 \%$ \\
\hline \multicolumn{3}{|c|}{ 5. Access to training on cooperative relations } \\
\hline Yes & 36 & $39.1 \%$ \\
\hline No & 56 & $60.9 \%$ \\
\hline
\end{tabular}

Source: Field survey, 2019.

In terms of age, Table 3 shows that there was a dominance of middle-aged (36-59 years) members and the youth ( $\leq 35$ years). All CBPs, except one had a mixture of different age categories. All respondents had some form of education, although none had acquired tertiary education. A minute number $(17.4 \%)$ of the respondents held social responsibility status from community development participation $(4.4 \%)$, religious affiliation $(7.6 \%)$ and 
political affiliation (5.4\%). As for access to training on cooperative relations, the majority (60.9\%) did not have access. This is identified as an area of possible improvement because the members' knowledge generally impacts their confidence level and participation (Getnet \& Anullo, 2012).

Table 4 shows the mean scores of the respondents when they were asked several questions related to group cohesion aspects of belonging (B) and morale (M). A five point Likert scale ranging from 1 (strongly disagree) to 5 (strongly agree) was adopted in the study, therefore, a mean score of above 3 indicated a certain level of agreement to the statement in question. Table 4 indicates that mean scores for all the questions were above 3 for CBP 8 . These results suggest that on overall, the members in this project had a significant sense of belonging and a feeling of morale associated with their membership in the group. These results are in agreement with the results on project member retention, where the project experiences a small annual average member exit value of 0.06 . In context, the results point out that the members have a strong attitude towards their project and are willing to continue participating as members. Even though CBP 8 is fairly new (established in 2014) as compared to the other projects in the study, regression results do not indicate a significant relationship between group cohesiveness and group stage.

Table 4. Descriptive statistics on group cohesion and member retention

\begin{tabular}{llllllllll}
\hline Group cohesion \& member retention indicators & \multicolumn{8}{c}{ Community-Based Project (CBP) } \\
\cline { 2 - 10 } & $\mathbf{1}$ & $\mathbf{2}$ & $\mathbf{3}$ & $\mathbf{4}$ & $\mathbf{5}$ & $\mathbf{6}$ & $\mathbf{7}$ & $\mathbf{8}$ & $\mathbf{9}$ \\
\hline Perceived cohesion (Group mean scores) & & & & & & & \\
1. I feel that I belong to this group. (B-1) & 2.00 & 2.15 & 2.14 & 2.60 & 1.20 & 3.09 & 3.06 & 3.95 & 1.33 \\
2. I am happy to be part of this group. (M-1) & 3.00 & 4.38 & 3.46 & 4.40 & 2.40 & 4.18 & 4.25 & 4.32 & 2.56 \\
3. I see myself as part of this group. (B-2) & 2.50 & 2.92 & 1.71 & 2.80 & 1.80 & 3.73 & 3.25 & 3.68 & 1.77 \\
4. This group is one of the best. (M-2) & 1.75 & 3.07 & 2.29 & 3.00 & 1.60 & 3.63 & 3.19 & 3.86 & 1.89 \\
5. I feel that I am a member of this group. (B-3) & 2.25 & 3.23 & 2.71 & 3.60 & 2.20 & 3.73 & 3.63 & 4.36 & 2.11 \\
6. I am content to be part of this group. (M-3) & 3.25 & 4.46 & 3.86 & 4.20 & 3.20 & 3.82 & 4.00 & 4.55 & 3.22 \\
Project member retention & & & & & & & & \\
Annual average member exit value & 0.43 & 0.16 & 0.38 & 0.19 & 0.67 & 0.12 & 0.13 & 0.06 & 0.51 \\
Member retention category & Bad & Fair & Bad & Fair & Bad & Fair & Fair & Good & Bad \\
\hline
\end{tabular}

Note. $\mathrm{N}=92$; B: Belonging; $\mathrm{M}$ : Morale.

Member retention: number of people that exit the project on yearly basis (yearly average) $[>20 \%$-Bad; 10 to 20\%-Fair; < 10\%-Good].

Source: Field survey, 2019.

Four community-based projects with the highest annual average member exit values [CBP 5(0.67); CBP 9(0.51); CBP 1(0.43) and CBP 3(0.38)] scored lower means on most of the group cohesion questions. These results support the argument that members who lack a sense of belonging to the group would not desire to continue associating with their cohorts (Paulus, 2012). However, it is interesting that all CBPs had mean scores of above 3 for the question related to contentedness in being part of their group. These results suggest that the members (including those in CBP 5, CBP 9, CBP 1 and CBP 3) are motivated to continue operating in a group because they receive some form of satisfaction from being part of a group. The only challenge is that if members receive minimal satisfaction from their group, they are bound to consider other attractive options. As such, projects that provide little satisfaction to its members are at risk of losing a significant number of members on a regular basis (Zeuli \& Bentancor, 2005). Such projects will suffer from instability because they will continuously need to adjust to the loss of members.

\subsection{Binary Logistic Regression Results}

Binary logistic regression results presented in Table 5 illustrate the factors that influence group cohesion in CBPs. The signs on the coefficients $(\beta)$ of the factors show the direction of the relationship with group cohesion and the $\beta$-value shows the magnitude of influence. In the table, the goodness-of-fit test determines the level of acceptance of the model. A p-value for the goodness-of-fit test $(\mathrm{p}=0.084)$ is higher than the $1 \%$ and $5 \%$ significance levels, which implies that the model is acceptable and the observed data is not statistically different from the expected values (Hilbe, 2015). The availability of many variables (17) in the model prompted the need to perform a correlation analysis before running the model, in order to eliminate the problem of multi-collinearity. 
The correlation analysis results indicate that there was not any significant relationship between the independent variables.

Five factors, which are financial performance, communication within the CBP, involvement in decision making, trust and role in the community, were significantly related to group cohesion in the study at either $1 \%$ or $5 \%$ significance level. All significant factors had a positive relationship with group cohesion, indicating that an improvement in these factors result in an increase in group cohesiveness. Among the significant factors, 'trust' had the highest $\beta$-value of 0.642 and is highly significant at $1 \%$ level, highlighting its great influence on group cohesion. These results substantiate results from Barraud et al., (2012) which recognized trust as a key indicator of group cohesion in cooperatives. Further explanations reveal that group members' desire to remain in a cooperative and their commitment to the group is highly dependent on trust. When group members develop trust amongst themselves and collectively in the cooperative, they actively participate in the cooperative's different affairs in favour of its success (Barraud et al., 2012).

Table 5. Regression results of factors influencing group cohesion in CBP

\begin{tabular}{|c|c|c|c|}
\hline \multirow{2}{*}{ Independent variable } & \multicolumn{2}{|c|}{ Unstandardized Coefficients } & \multirow{2}{*}{ Sig. $(p)$} \\
\hline & Coef. $(\beta)$ & Std. Error & \\
\hline (Constant) & .129 & .098 & .042 \\
\hline \multicolumn{4}{|l|}{ 1. Demographic factors } \\
\hline Gender & .037 & .078 & .163 \\
\hline Education & -.122 & .038 & .124 \\
\hline Age & .088 & .071 & .398 \\
\hline \multicolumn{4}{|l|}{ 2. Economic factors } \\
\hline Financial performance & .235 & .068 & $.001 * * *$ \\
\hline Value addition practice & .119 & .072 & .237 \\
\hline Accessibility of CBP produce to members & .134 & .009 & .195 \\
\hline \multicolumn{4}{|l|}{ 3. Organizational factors } \\
\hline Communication within the $\mathrm{CBP}$ & .174 & .011 & $.048 * *$ \\
\hline Leaders' capability & .289 & .045 & .276 \\
\hline Involvement in decision making & .188 & .112 & $.033 * *$ \\
\hline Cooperative training & .311 & .013 & .192 \\
\hline External influence & -.023 & .065 & .215 \\
\hline \multicolumn{4}{|l|}{ 4. Psychological } \\
\hline Trust & .642 & .087 & $.000 * * *$ \\
\hline Group size & .136 & .087 & .109 \\
\hline Group stage & .245 & .106 & .127 \\
\hline Group composition & .167 & .038 & .321 \\
\hline \multicolumn{4}{|l|}{ 5. Social factors } \\
\hline Member social networking & .198 & .091 & .283 \\
\hline Role in the community & .203 & .036 & $.042 * *$ \\
\hline $\mathrm{R}^{2^{\prime}}$ & .844 & & \\
\hline Adjusted $\mathrm{R}^{2}$ & .816 & & \\
\hline Goodness-of-fit test & Chi-square & df & Sig.(p) \\
\hline Pearson & 187.354 & 91 & .084 \\
\hline Deviance & 86.109 & 91 & .812 \\
\hline
\end{tabular}

Note. $N=92 ; * * *, * *$ indicate significance at $1 \%$ and $5 \%$ level respectively.

Source: Field survey, 2019.

The variable 'financial performance' of the cooperative was highly significant $(p=0.001)$, which portrays the importance of financial gains in cooperative relations. These results support assertions from Österberg and Nilsson (2009) that cooperatives' good financial performance brings members commitment and satisfaction. In general, people engage in cooperative relations for financial gains. If they fail to see any financial benefits in 
cooperatives, they will not have an incentive to remain participating. Therefore, collective relations need to be entwined with financial incentives for the members to stay with their organization (Österberg \& Nilsson, 2009; Zeuli \& Bentancor, 2005). These results explain why a number of CBPs in the study lost members after government departments withdrew stipends; guaranteed financial gains were removed and members were not sure of the cooperatives' financial future.

'Role in the community' was statistically significant at the $5 \%$ level and had a $\beta$-value of 0.203 . This variable represents the role that the cooperative takes in the community, particularly in improving the lives of community members. The results indicate that the higher the cooperative's activities are recognised in the community, the more the cooperative members are commitment to their cooperative. This variable is closely related to people's esteem-generally, humans seek to be associated with winning teams. Thus, a cooperative that performs distinguishable work in the community attracts many members (Tuna \& Karantininis, 2017).

One of the organizational factors that was statistically significant at the $5 \%$ level is 'involvement in decision making.' The positive relationship between this variable and group cohesion denotes that members easily form strong ties in organizations where they are involved in making organizational decisions. When members perceive that their ideas are valuable in an organization, they become committed. According to Borgen (2001), it is easy for members to participate actively towards implementing decisions that they contributed. Involvement of members in decision making helps in developing a sense of member inclusiveness and acceptance in the cooperative, which ultimately strengthen their emotional attachment and commitment to the cooperative. Dakurah et al. (2005) emphasise the importance of members' involvement in decision making towards long term survival and growth of an organization.

'Communication within the CBP' is another organizational factor that was statistically significant at the $5 \%$ level and had a $\beta$-value of 0.174 . Effective communication within a cooperative has always been advocated for increased participation among members (Taruvinga et al., 2017; Österberg \& Nilsson, 2009). Effective communication embraces the channels, timeliness, language and quality of information, and the ability to raise concerns and receive feedback. An effective communication system is vital for disseminating information, coordinating tasks and keeping members informed of the direction of their cooperative. It also helps in creating social ties among cooperative members. The existence of an effective communication system influences the commitment of members and the success of an organization (Österberg \& Nilsson, 2009).

\section{Conclusion}

The study investigated the factors that influence member commitment to their Community-based projects and their willingness to remain part of the organization, by utilizing a survey approach. Evidence from the study shows that there are several factors of consideration that guide people to continue participating or exit a cooperative. Five variables namely: financial performance, communication within the CBP, involvement in decision making, trust and role in the community, were statistically significant at either $1 \%$ or $5 \%$ level. The variables represented economic, social, psychological and organizational factors. Out of all the significant variables, 'trust' was identified as the most important indicator in influencing group cohesion. The explanations provided indicated that trust instils a sense of belonging and commitment among members to perform economic activities. Members that are driven by trust are willing to nature the functionality of the cooperative organization, and motivated to remain part of the organization for longer periods. Financial performance of a cooperative was also identified as an important indicator because people mostly engage in cooperative relations for financial gains. This is supported by tendency of people to exit an organization upon exposure to the availability of other options offering better financial gains. Communication within the CBP, involvement in decision-making and role in the community influence group cohesion and member commitment through creating a sense of recognition and importance.

Based on the results of the study, there are several recommendations that can be made in order to enhance group cohesion in agricultural cooperatives. Standards need to be set at cooperative formation stage. There is need for transparency and information sharing, from the commencement of the cooperative. In addition, members should agree on a clear code of conduct, communication channels and members' responsibilities. That way, members will have a clear vision of the cooperative and their roles and responsibilities in the organization. Moreover, transparency is essential in creating trust among members. The responsibility of planning, budgeting and evaluating performance of the cooperative should be done collectively, with the consultation of all members. This will assist towards setting measurable and practical goals, and in building knowledge among members regarding financial opportunities from the cooperative. The knowledge on internal financial opportunities will 
shift their focus from the external financial support (which is not sustainable) towards suggestions that improve internal finances.

\section{References}

Barraud, D. V., Henninger, M. C., \& El Akremi, A. (2012). The relationship between members' trust and participation in the governance of cooperatives: The role of organizational commitment. International Food and Agribusiness Management Review, 15(1), 1-24.

Bernard, T., Abate, G. T., \& Lemma, S. (2013). Agricultural cooperatives in Ethiopia: Results of the 2012 ATA Baseline Survey. The International Food Policy Research Institute (IFPRI). Washington, DC.

Bijman, J., \& Verhees, F. (2011). Member or customer? Farmer commitment to supply cooperatives. International Conference on the Economics and Management of Networks.

Bollen, K. A., \& Hoyle, R. H. (1990). Perceived Cohesion: A conceptual and empirical examination. Social Forces, 69(2), 497-504. https://doi.org/10.2307/2579670

Borgen, S. (2001). Identification as a Trust Generating Mechanism in Cooperatives. Annals of Public and Cooperative Economics, 72(2), 209-228. https://doi.org/10.1111/1467-8292.00165

DAFF (Department of Agriculture Forestry and Fisheries). (2010). The Strategic Plan for South African Agriculture. Department of Agriculture, Directorate of Agricultural Information Services, Pretoria.

Dakurah, H. A., Goddard, E., \& Osuteye, N. (2005). Attitudes towards and satisfaction with cooperatives in Alberta: A survey analysis (pp. 24-27). American Agricultural Economics Association Annual Meeting, Providence, Rhode Island.

Develtere, P., Pollet, I., \& Wanyama, F. (2008). Cooperating out of poverty: The renaissance of the African cooperative movement. ILO.

Evans, C. R., \& Dion, K. L. (2012). Group cohesion and performance a meta-analysis. Small Group Research, 43(6), 690-701. https://doi.org/10.1177/1046496412468074

FAO (Food and Agriculture Organization of the United Nations). (2012). Agricultural cooperatives key to feeding the world. Retrieved on January 20, 2021, from http://www.fao.org/fileadmin/templates/ getinvolved/images/WFD2012_leaflet_en_low.pdf

Forsyth, D. R. (2006). Group Dynamics (4th ed.). Thomson/Wadsworth, Belmont.

Francesconi, G. N., \& Heerink. N. (2011). Ethiopian agricultural cooperatives in an era of global commodity exchange: Does organisational form matter? Journal of African Economies, 20(1), 153-177. https://doi.org/ 10.1093/jae/ejq036

Garnevska, E., Liub, G., \& Shadbolt, N. M. (2011). Factors for Successful Development of Farmer cooperatives in Northwest. International Food and Agribusiness Management Review, 14(4), 69-84.

Getnet, K., \& Anullo, T. (2012). Agricultural cooperatives and rural livelihoods: Evidence from Ethiopia. Annals of Public and Cooperative Economics, 83(2), 181-198. https://doi.org/10.1111/j.1467-8292.2012.00460.x

Gikunda, R. M., \& Lawver, D. E. (2019). Group cohesion and application of best horticultural farming practices among farmer groups in Meru County. Kenya. Journal of international Agricultural and Extension Education, 26(1), 60-72. https://doi.org/10.5191/jiaee.2019.26106

Hakelius, K. (1999). Farmer cooperatives in the 21st century: young and old farmers in Sweden. Journal of Rural Cooperation, 27(1). 31-54.

Hansen, M. H., Morrow Jr., J. L., \& Batista, J. C. (2002). The impact of trust on cooperative membership retention, performance, and satisfaction: An exploratory study. The International Food and Agribusiness Management Review, 5(1), 41-59. https://doi.org/10.1016/S1096-7508(02)00069-1

Hilbe, J. M. (2015). Practical guide to logistic regression. Chapman and Hall, Boca Raton. https://doi.org/ $10.1201 / \mathrm{b} 18678$

ICA (International Cooperative Alliance). (1995). Statement on the Cooperative Identity. Review of International Cooperation, 88(3), 12.

Ito, J., Bao, Z., \& Su, Q. (2012). Distributional effects of agricultural cooperatives in China: exclusion of smallholders and potential gains on participation. Food Policy, 37, 700-709. https://doi.org/10.1016/ j.foodpol.2012.07.009 
Jussila, I., Goel, S., \& Tuominen, H. (2012). Member commitment in co-operatives: The utilitarian approach. Business and Management Research, 1(3), 9-16. https://doi.org/10.5430/bmr.v1n3p9

Khapayi, M., \& Celliers, P. R. (2016). Factors limiting and preventing emerging farmers to progress to commercial agricultural farming in the King Williams Town area of the Eastern Cape Province, South Africa. South African Journal of Agricultural Extension, 44(1), 25-42. https://doi.org/10.17159/2413-3221/ 2016/v44n1a374

Nkonki-Mandleni, B., \& Anim, F. D. K. (2014). Determining factors of support for co-operatives in South Africa. Journal of Human Ecology, 47(2), 171-174. https://doi.org/10.1080/09709274.2014.11906750

Österberg, P., \& Nilsson, J. (2009). Members' perception of their participation in the governance of cooperatives: The key to trust and commitment in agricultural cooperatives. Agribusiness, 25(2), 181-197. https://doi.org/ 10.1002/agr.20200

Paulus, W. (2012). Strengthening member commitment in agricultural cooperatives: An overview on how Dutch agricultural cooperatives seek to strengthen the commitment of their members. Wageningen, The Netherlands: Wageningen University, Management Studies.

Taruvinga, B., Ndou, P., Hlerema, I. N., Maraganedzha, T. L., du Plooy, C. P., \& Venter, S. (2017). Fostering linking social capital for successful agricultural development projects in South Africa. Agrekon, 56(1), 28-39. https://doi.org/10.1080/03031853.2017.1283243

Trechter, D. D., King, R. P., \& Walsh, L. (2002). Using communications to influence member commitment in cooperatives. Journal of Cooperatives, 17, 14-30.

Tuna, E., \& Karantininis, K. (2017). Cooperatives as agents of social capital: An evidence from a post-socialist country. International Congress, August 28-September 1, 2017, European Association of Agricultural Economists, Parma, Italy.

Wanyama, F. O., Develtere, P., \& Pollet, J. (2009). Reinventing the wheel? African cooperatives in a liberalized economic environment. Annals of Public and Cooperative Economics, 80(3), 361-392. https://doi.org/ 10.1111/j.1467-8292.2009.00390.x

Wiggins, S., Argwings-Kodhek, G., Leavy, J., \& Poulton, C. (2011). Small farm commercialisation in Africa: Reviewing the issues September 2011 (Research Paper 023). Retrieved July 20, 2020, from http://citeseerx.ist.psu.edu/viewdoc/download?doi=10.1.1.360.7442\&rep=rep1 \&type=pdf

Yang, H., Klerkx, X., \& Leeuwis, C. (2013). Functions and limitations of farmer cooperatives as innovation intermediaries: Findings from China. Agricultural Systems, 127, 115-125. https://doi.org/10.1016/j.agsy. 2014.02.005

Zeuli, K. A., \& Bentancor, A. (2005). The effects of cooperative competition on member loyalty. 2005 Annual Meeting, November 8-9, NCERA-194 Research on Cooperatives.

\section{Appendix A}

\section{Perceived Cohesion Measures}

1. I feel that I belong to this group. (B-1)

2. I am happy to be part of this group. (M-1)

3. I see myself as part of this group. (B-2)

4. This group is one of the best anywhere. (M-2)

5. I feel that I am a member of this group. (B-3)

6. I am content to be part of this group. (M-3)

Source: Bollen and Hoyle (1990).

\section{Copyrights}

Copyright for this article is retained by the author(s), with first publication rights granted to the journal.

This is an open-access article distributed under the terms and conditions of the Creative Commons Attribution license (http://creativecommons.org/licenses/by/4.0/). 